九州大学学術情報リポジトリ

Kyushu University Institutional Repository

Relationships between Development Time, Reproductive Period, Fecundity and Longevity at the Within-individual Level in the Cowpea Aphid Aphis craccivora Koch (Homoptera: Aphididae)

MOUSA, M. Kareem

Economic Entomology Department, Faculty of Agriculture, Kafrelsheikh University

RAKHA, M. Osama

Economic Entomology Department, Faculty of Agriculture, Kafrelsheikh University

UEN0, Takatoshi

Laboratory of Insect Natural Enemies, Division of Biological Control, Department of Applied Genetics and Pest Management, Faculty of Agriculture, Kyushu University

https://doi.org/10.5109/2232292

出版情報: 九州大学大学院農学研究院紀要. 64 (1)，pp.101-106，2019-02-28. Faculty of Agriculture, Kyushu University

バージョン：

権利関係 : 


\title{
Relationships between Development Time, Reproductive Period, Fecundity and Longevity at the Within-individual Level in the Cowpea Aphid Aphis craccivora Koch (Homoptera: Aphididae)
}

\author{
Kareem M. MOUSA ${ }^{1}$, Osama M. RAKHA ${ }^{1}$ and Takatoshi UENO* \\ Laboratory of Insect Natural Enemies, Division of Biological Control, Department of Applied Genetics \\ and Pest Management, Faculty of Agriculture, Kyushu University, Fukuoka 819-0395, Japan \\ (Received October 31, 2018 and accepted November 12, 2018)
}

\begin{abstract}
The cowpea aphid or groundnut aphid Aphis craccivora Koch (Homoptera: Aphididae) is often a serious pest of legume crops like cowpea and faba bean. The internal biological or life history traits, such as development, fecundity and longevity, are of particular importance to understand and predict population dynamics of pest insects. The present study focused on the individual variation and within-individual correlations between or among such important traits in A. craccivora. For this purpose, aphids were individually reared and observed throughout their lifetime. The results revealed that pre-viviparity period, i.e., the time required for the first offspring production after adult molting, correlated positively with the developmental time but negatively with the reproductive period, i.e., the number of days in which the aphid produced the offspring. The reproductive period correlated negatively with the development time and, curiously, positively with the lifetime fecundity. Thus, the aphids that develop faster reproduce for a longer period of time but produce fewer offspring. The post-reproductive period, i.e., the number of days in which adult female remained live after the last offspring production, positively correlated with the total fecundity, suggesting a disappearance of the reproductive cost. A significant negative correlation was also detected between the lifetime fecundity and reproductive period, demonstrating a cost of reproduction. We discussed the factors affecting individual variations in the life history parameters of aphids and the trade-offs between the parameters.
\end{abstract}

Key words: pest management, trade-offs, life history, faba bean, viviparity, individual variation

\section{INTRODUCTION}

Aphids are one of the most serious pests in crop protection. They are a group of soft-bodied, piercing-sucking insects that feed on plant fluids (Auclair, 1963; Vilcinskas, 2016) and can cause leaf-yellowing, plant stunting, wilting, and eventually death (Blackman and Eastop, 2000; van Emden and Harrington, 2007; Vilcinskas, 2016). Also, aphids produce honeydew, which can stimulate pathogenic infection (Dhami et al., 2013). Furthermore, they are of particular importance as disease vectors, carrying and spreading various plant viral diseases (Blackman and Eastop, 2000; Ng and Falk, 2006). Recent studies have shown that aphids can also be vectors of bacterial diseases (Stavrinides et al., 2009). Aphids infesting agricultural crops can thus have a major impact on food production.

Many insect pests are known to attack legumes (Singh and van Emden, 1979; Singh, 1990) and can cause great yield losses in Africa (Alghali, 1992; Rusoke and Rubaihayo, 1994; Karungi et al., 2000). Cowpea and broad bean (= faba bean) are major and important legume crops in Africa, including Egypt (Nassib et al., 1991; Darwish and Abdalla, 1997; Morad et al., 2007). Insect pest management is crucial to stable production of legume crops, and aphids are the major targets of control.

The cowpea aphid or groundnut aphid Aphis craccivora Koch (Homoptera: Aphididae) is originated from

\footnotetext{
Economic Entomology Department, Faculty of Agriculture, Kafrelsheikh University, Kafr El-Sheikh, Egypt

* Corresponding author (E-mail: ueno@grt.kyushu-u.ac.jp)
}

Palearctic region but is now an invasive pest species widely occurring in the world (Blackman and Eastop, 2000; CABI, 2018). This aphid species infests a wide variety of plants but prefers Leguminosae (= Fabaceae) such as Medicago, Trifolium and Vicia (Singh and van Emden, 1979; Blackman and Eastop, 2000). It attacks seedling, vegetative and flowering stages of host plants. Aphis craccivora can transmit more than 20 species of plant virus diseases (Blackman and Eastop, 2000; CABI, 2018). While several species of aphids cause legume crop losses, the cowpea aphid is a serous pest in terms of the transmission of plant diseases. Thus, this aphid is one of the major targets of pest management in legume crops; A. craccivora is known as an important pest of bean crops like cowpea and faba bean in Egypt (e.g., Kamel, 1982) and other African countries (e.g., Alghali, 1992; Karungi et al., 2000).

Aphids, including A. craccivora, often show a high degree of seasonality, in particular, in areas where climate conditions changes dramatically depending on the seasons (e.g., Singh and van Emden, 1979; Mousa and Ueno, 2019). Understanding the dynamics of pest population has been one of the central subjects in the research field of pest management (Cammell and Knight, 1992; Reuveni, 1995; van Emden and Harrington, 2007; Abrol, 2014). Pest population growth, size and dynamics are determined primarily by internal biological parameters such as size, development, fecundity, longevity and mortality rate (Thomas, 1999; Wang and Shipp, 2001) and also by external biological factors such as immigration and emigration as well as non-biological factors such as temperature (Cammell and Knight, 1992; 
Gilbert and Raworth, 1996). The internal biological traits therefore are of particular importance to predict population dynamics of the pest species. A countless number of studies have been made to reveal such biological parameters of insect pests, including aphids.

Thus, developmental time, longevity and fecundity are the fundamental properties of life history and biology of insect pests (Abrol, 2014). Such biological parameters are however not independent for each other; they can be mutually related because of the presence of trade-offs between or among the traits (Stearns, 1989; 1992). For example, a decrease in development time is likely to relate closely to a decrease in body size (e.g., Kiorboe and Hirst, 2008). Hence, individuals that develop quickly can be small in size and then have a low potential fecundity. Revealing the trade-offs or relationships between or among life history traits should therefore be crucial to fundamental understanding of pest life history and biology. However, such trade-offs can often be unclear when the averaged data or among-individual data are used because individual variation makes it obscure to detect such relationships. Accordingly, studies focusing on the within-individual relationships are essential to investigating life history parameters.

In the present study, we investigate some of important life history parameters of cowpea aphid and examine the relationships between the parameters at the within-individual level. Based on the results, we discuss the factors influencing individual variations in the life history parameters and the trade-offs between the parameters in A. craccivora.

\section{MATERIALS AND METHODS}

\section{Aphid colony}

Colonies of the cowpea aphid were collected from an open field of cowpea at Gharbia Governorate, Egypt, and returned to the laboratory to build up the culture. The aphids were maintained on seedlings of broad bean (= faba bean) Vicia faba (Fabaceae) in an incubator kept at $25 \pm 1^{\circ} \mathrm{C}$ under a photoperiod of 12:12 h (L:D). Broad bean cultivars Sakha 1 obtained from Agricultural Research Center, Sakha, Kafr El-sheikh was used to rear the aphids. When necessary, aphids were transferred to new bean plants by the use of a painting brush.

\section{Experimental set-up}

We examined individual variation in life history traits of the cowpea aphid as follows: One broad bean seedling was allowed to grow in a pot filled with sand with $\mathrm{pH}$ conditions between 6.2 and 7.2. Within this range, $\mathrm{pH}$ does not affect the aphid performance (Mousa et al., in preparation). Each of seedlings with 3 leaves were then placed in a glass cage $(30 \mathrm{~cm}$ in height, $8 \mathrm{~cm}$ in diameter) with a muslin cloth mesh on the top to provide air circulation and to prevent aphid migration to other plants.

Then, an apterous viviparous female of A. craccivora was randomly selected and was carefully transferred onto the seedling in the cage. After $12 \mathrm{~h}$, the adult and its entire offspring were removed from the seedling with a camelhair brush 0 size, except one newly born nymph; thus, an experimental set-up with one aphid nymph on a bean seedling was prepared. Glass cages were placed in an environmental growth chamber kept at $25 \pm 1^{\circ} \mathrm{C}, 70 \pm 5 \% \mathrm{RH}$ under a photoperiod of 16:8 (L:D) h.

The cages were observed on the daily basis using a 10X binocular stereomicroscope to examine the biological parameters, such as the duration of nymphal stage (from birth to adult emergence), adult longevity and reproductive period (including pre-reproductive and post-reproductive). When the fourth molting, i.e., molting to an adult female, was confirmed, the test aphids were observed hourly to examine pre-viviparity period, i.e., the time required to produce the first offspring. Each adult female was checked for offspring production, and newborn nymphs were counted and removed daily until the adult death to estimate the daily and total fecundity. The data were analyzed with the aid of JMP version 9 (JMP, 2010).

\section{RESULTS}

All measured traits or parameters of life history showed a considerable variation. The mean developmental time of Aphis craccivora in our experimental condition was $7.70 \pm 1.53$ days (with $\mathrm{SD}, \mathrm{n}=20$ ). The mean reproductive and post-reproductive periods were $6.75 \pm 2.05$ and $2.65 \pm 0.88$ days, respectively. Thus, the mean total life span was $17.1 \pm 12.1$ days. The mean pre-viviparity period was $0.91 \pm 0.14$ days. Finally, lifetime fecundity was $18.2 \pm 11.0$ per female aphid.

Then, correlations among the parameters were statistically examined at the within-individual level. The development time of $A$. craccivora correlated negatively with the reproductive period, i.e., the number of days in which the aphid produced the offspring (Fig. 1a; $\mathrm{n}=20$, $r^{2}=0.70, F=41.0, P<0.0001$ ) but positively did so with the lifetime fecundity (Fig. $1 \mathrm{~b} ; r^{2}=0.28, F=6.68, P=$ 0.019). The pre-viviparity period, i.e., the time required for the first offspring production after adult molting, was found to correlate positively with the development time (Fig. $2 \mathrm{a}$; $r^{2}=0.72, F=45.7, P<0.0001$ ) but negatively correlated with the reproductive period (Fig. $2 \mathrm{~b} ; r^{2}=$ $0.45, F=14.7, P=0.0012)$. Other parameters were not significantly related $(P>0.05)$. The post-reproductive period, i.e., the number of days in which adult female remained live after the last offspring production, significantly correlated with the lifetime fecundity (Fig. $3 ; r^{2}=$ $0.23, F=5.49, P=0.031$ ) but the other parameters did not $(P>0.05)$.

A positive relationship was detected between the total life span and the reproductive period (Fig. $4 \mathrm{a} ; r^{2}=$ $0.48, F=16.4, P=0.0008)$. The total life span was marginally related with the post-reproductive period $\left(r^{2}=\right.$ $0.19, F=4.14, P=0.056)$ but not with the developmental time $\left(r^{2}=0.15, F=3.10, P=0.096\right)$. The pre-viviparity period did not relate significantly with total life span $(P>0.05)$. Finally, a regression analysis demon- 

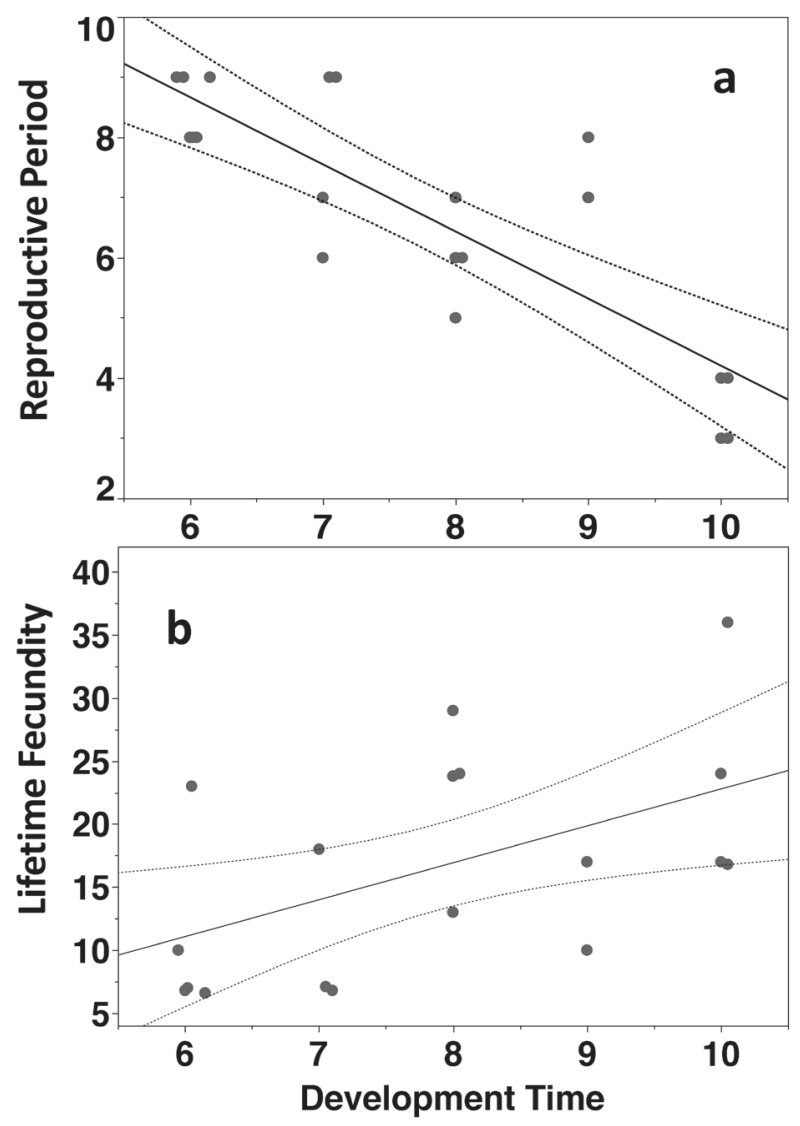

Fig. 1. The relationship between developmental time (days) and reproductive period (days) (a) or lifetime fecundity in $A$. craccivora. A significant regression line (solid line) together with $95 \%$ confidence interval lines (dotted lines) is shown on each figure.

strated a strong negative correlation between the fecundity and reproductive period (Fig. 4b; $r^{2}=0.60, F=25.5$, $P<0.0001)$.

\section{DISCUSSION}

Insects commonly show individual differences in life history traits. The present study also has demonstrated that the performance of the aphid A. craccivora greatly varies among individuals. Such differences may arise because of genetic differences. In aphids, several traits have been demonstrated to be under a genetic control (Groeters, 1989; Hazell et al., 2005; Brisson, 2010). Also, the other external and internal factors that are not always controlled even in the laboratory condition may be involved in individual differences or variations. For example, insect behavior is reported to be variable depending on internal physiological or nutritional state, which can experimentally be difficult to control (Minkenberg et al., 1992; Ueno, 1999; Ueno and Ueno, 2005, 2007). In the study of herbivorous insects like aphids, host plant quality may also be an explanation. Even in the laboratory condition, plant physiological and physical conditions cannot perfectly be controlled, which may result in differences of herbivores' performance; host plant quality is known to be an important determi-

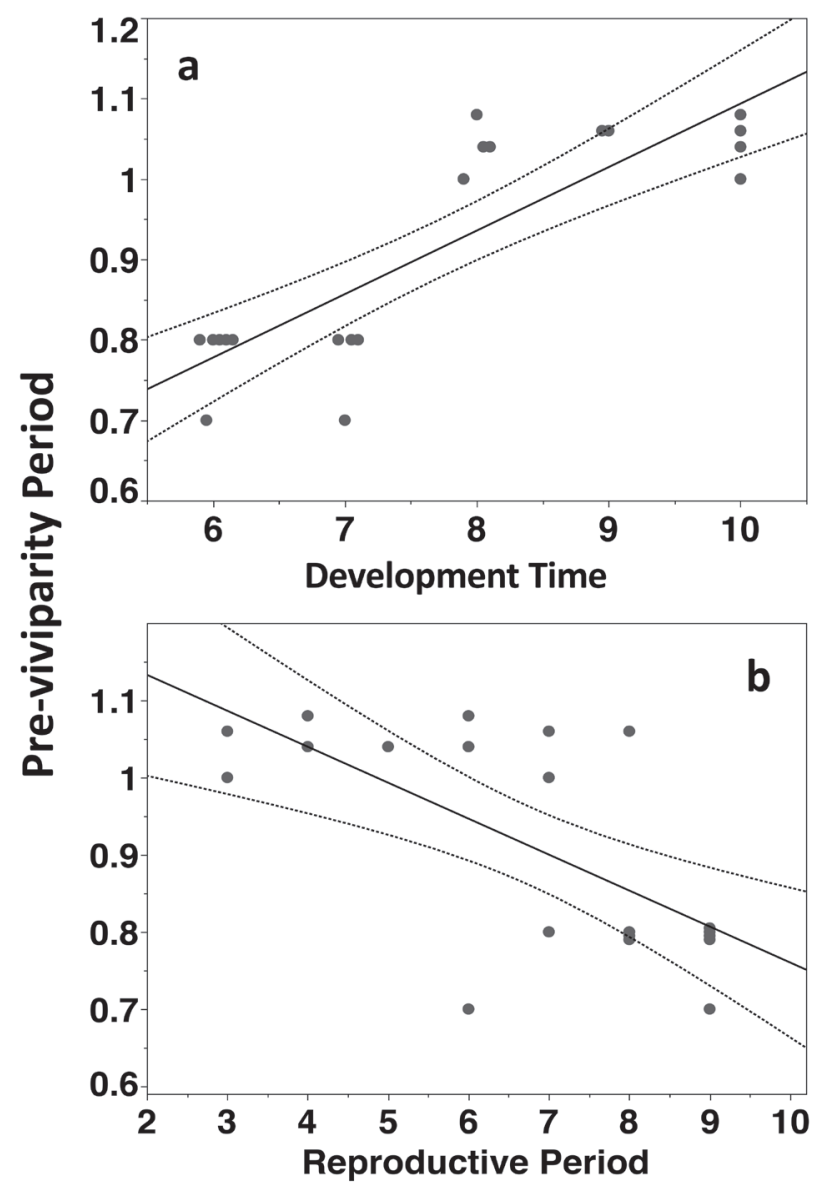

Fig. 2. The relationships between pre-viviparity period in days and developmental time (a) or reproductive period in days (b) in A. craccivora. A significant regression line (solid line) together with $95 \%$ confidence interval lines (dotted lines) is shown in each figure.

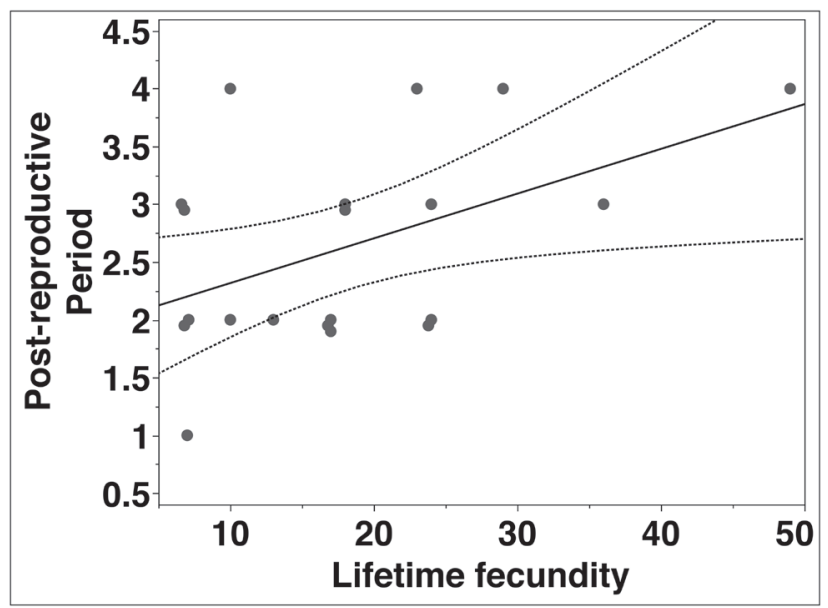

Fig. 3. The relationship between lifetime fecundity and postreproductive period (days) in $A$. craccivora. A significant regression line (solid line) together with 95\% confidence interval lines (dotted lines) is shown.

nant affecting many aspects of insect herbivores (Awmack and Leather, 2002).

Less frequently reported phenomena are how each of traits exhibiting variation can mutually be linked. The 


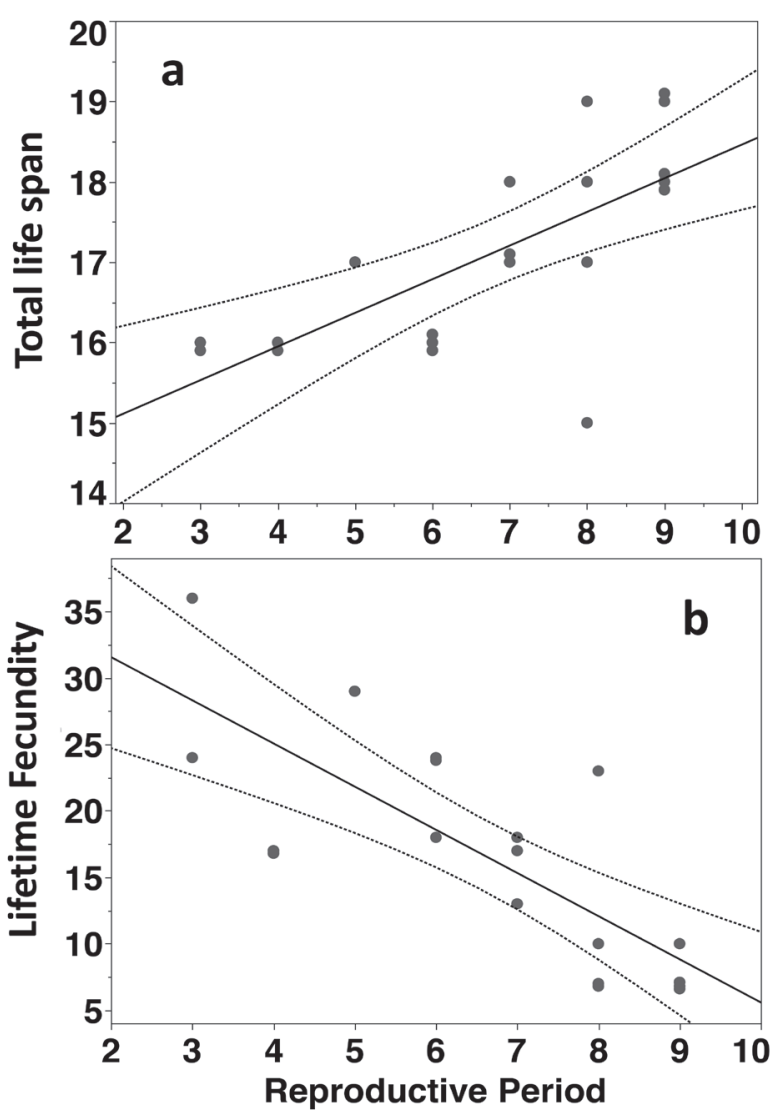

Fig. 4. The relationships between reproductive period and total life span (days) (a) or lifetime fecundity (b) in A. craccivora. A significant regression line (solid line) together with 95\% confidence interval lines (dotted lines) is shown on each figure.

present paper has focused on the relationships between development time, fecundity, pre-viviparity, reproductive and post-reproductive periods at the within-individual level of the aphid A. craccivora. Our study has indicated that such life history parameters are mutually linked.

The present study has revealed that $A$. craccivora that develop slower reproduce for a shorter period of time (Fig. 1a). If longer development time indicates poorer condition for the aphid during the development, we may expect shorter reproductive period and lower lifetime fecundity. The present results have revealed a negative, rather than the predicted positive, correlation; A. craccivora that develops slower and reproduces for a shorter period can produce more offspring during the lifetime (Fig. 1b and 4b). Instead, such individual aphids live shorter (Fig. 4a). Thus, our study shows that $A$. craccivora that develops slower lives shorter but produces more offspring.

The theory of life history evolution generally predicts a negative relationship between fecundity and longevity (Stearns, 1992; Kiorboe and Hirst, 2008); investment of limited nutritional resources in reproduction can be at the expense of investment in somatic maintenance, which should lead to shortened lifespan. A higher-rate reproductive performance may also lead to faster aging, again resulting in a shorter lifespan. In the present study, we detected a clear negative relationship between the lifetime fecundity and reproductive period in $A$. craccivora (Fig. 4b). This result supports the general idea of the theory. Curiously, the aphids with higher fecundity instead had a higher life expectancy once they had ceased offspring production (Fig. 3). Increased early-reproductive investment does not incur later cost during the life after reproduction. This may be because such highly reproductive individuals originally are physiologically or physically superior so that they can live long in the remainder of their life in the absence of the cost of reproduction.

Also, in the present study, the pre-viviparity period of cowpea aphids was longer when the development time was longer or the reproductive period is shorter (Fig. 2a). Taken together, though we did not measure the size of aphids, we suspect that the aphids become larger in size require more time to develop but their reproductive potential become higher, resulting in faster and greater reproduction. Pre-viviparity period may reflect the nutritional or physiological state of individual female aphids, and longer period may suggest female aphids of better state, maturing more offspring at the earliest stage of reproduction, and, when they start reproducing, they produce more offspring and die faster.

Factors causing the observed variation among aphid individuals are unknown. We suspect that the observed differences may, at least in part, be explained by the difference in host plant quality. The quality of host plants has profound numerous impacts on the reproductive performance of insect herbivores, including aphids (Awmack and Leather, 2002). We did not measure the nutritional quality among bean plants used in our experiment but we noticed the seedling heights differed among bean plants even in the same growth condition, suggesting the presence of physiological or physical differences among bean plants. Alternatively, the differences may arise due to genetic variation among the aphids. Additional experiments are needed to separate the effects of genetic background from host plant effects.

The aphid management are often difficult and complex because they may rapidly develop resistance to chemical insecticides and because they can increase very rapidly (Singh, 1990; Vilcinskas, 2016). Thus, an integrated pest management system is required. As with the other crop production systems, chemical control of aphids is often a major practice in the bean fields (Singh, 1990; Alghali, 1992). Efforts are, however, needed to develop environmentally benign aphid management systems. Cultural and biological control methods may be effective practices (Reuveni, 1995; Thomas, 1999; Abrol, 2014). For example, conserving natural enemies by an intercropping system and using pesticides only when necessary can be a good practice (Mousa and Ueno, 2019). Sprays of botanical pesticides can be organically accepted methods to combat aphids. For example, the extract from some plant materials have insecticidal action and can be used for control aphids and other insect pests (Mousa et al., 2013; Tran et al., 2016, 2017). 
Alternatively, use of resistant varieties may be a good option for aphid management (Ofuya, 1993; Hafiz, 2006; Laamari et al., 2008; Soffan and Aldawood, 2014). In Egypt, there are many varieties of cowpea and faba bean that have different biological characteristics (e.g., Darwish and Abdalla, 1997; Hafiz, 2006; El-Shaieny et al., 2015). New crop varieties showing resistance or tolerance to aphids can therefore be developed with Egyptian varieties.

The lifetime fecundity recorded in the present study appears to be rather low. For example, available data from previously published studies, in which $A$. craccivora has been reared at $25^{\circ} \mathrm{C}$, demonstrate that the lifetime fecundity are 31-45 with the reproductive period ranging between 12 and 18 days depending on faba bean varieties (Soffan and Aldawood, 2014) and between 16.3 and 28.4 depending on cowpea varieties (Hafiz, 2006), the values of which are evidently higher than the value obtained in our study (fecundity and reproductive period were 18.2 and 6.75 days, respectively). Likewise, adult longevity recorded in our study is shorter than that in some previous studies (for example, 16.4 days in Jalalipour et al., 2017). Thus, biological parameters of $A$. craccivora appear to be highly variable. We do not know the reason but the broad bean used here may be somewhat resistant to the aphid. Alternatively, such differences may arise due to the presence of geographical strains that differ in life history traits. In any case, selection of resistant varieties would be a future subject to establish the integrated pest management program for bean production in Egypt.

\section{AUTHOR CONTRIBUTIONS}

K. M. Mousa designed and conducted the experiment. O. M. Rakha helped during the experiments. T. Ueno analyzed the data and prepared the first draft of the manuscript.

\section{REFERENCES}

Alghali, A. M. 1992 Insecticide application schedules to reduce grain yield losses caused by insect pests of cowpea in Nigeria. Insect Sci. Appl., 38: 420-424

Abrol, D. P. 2014 Integrate Pest Management: Current Concept and Ecological Perspective, Academic Press, London

Auclair, J. L. 1963 Aphid feeding and nutrition. Annu. Rev. Entomol., 8: 439-490

Blackman, R. L. and V. F. Eastop 2000 Aphids on the World's Crops: an Identification and Information Guide, 2nd ed. J. Wiley, London, England

Awmack, C. S. and S. R. Leather 2002 Host plant quality and fecundity in herbivorous insects. Annu. Rev. Entomol., 47: 817-844

Brisson, J. A. 2010 Aphid wing dimorphisms: linking environmental and genetic control of trait variation. Phil. Trans. Royal Soc. B., 365: 605-616

CABI 2018 Aphis craccivora. Invasive Species Compendium

Cammell, M. E. and J. D. Knight 1992 Effects of climatic change on the population dynamics of crop pests. Adv. Ecol. Res., 22: $117-162$

Darwish, D. S. and M. M. F. Abdalla 1997 Faba bean breeding in Egypt. Egypt. J. Plant Breed., 1: 115-139

El-Shaieny A. A. H., Y. Y. Abdel-Ati, A. M. El-Damarany and A. M.
Rashwan 2015 Stability analysis of components characters in cowpea (Vigna unguiculata (L.) Walp). J. Hort. Forest., 7: 24-35

Gilbert, N. and D. A. Raworth 1996 Insects and temperature-a general theory. Can. Entomol., 128: 1-13

Groeters, F. R. 1989 Geographic and clonal variation in the milkweed-oleander aphid, Aphis nerii (Homoptera: Aphididae), for winged morph production, life history, and morphology in relation to host plant permanence. Evol. Ecol., 3: 327-341

Hafiz, N. A. 2006 Use of life tables to assess host plant resistance in cowpea to Aphis craccivora Koch (Homoptera: Aphididae). Ass. Univ. Bull. Environ. Res., 9: 1-6

Hazell, S. P., D. M.Gwynn, S. Ceccarelli and M. D. E. Fellowes 2005 Competition and dispersal in the pea aphid: clonal variation and correlations across traits. Ecol. Entomol., 30: 293-298

Ho, T. T. G., C. V. Le, T. H. Nguyen, T. Ueno and D. V. Nguyen 2013 Incidence of yellow rice stem borer Scirpophaga incertulas Walker in Haiphong, Vietnam and control efficacy of egg mass removal and insecticides. J. Fac. Agric., Kyushu Univ., 58: $301-306$

Jalalipour, R., A. Sahragard, K. Madahi and A. Karimi-Malati 2017 Comparative life table of Aphis craccivora (Hem.: Aphididae) on host plant, Robinia pseudoacacia under natural and laboratory conditions. J. Entomol. Soc. Iran, 36: 249-257

JMP 2010 JMP version 9.0. SAS Institute Inc., Cary, NC

Kamel, A. H. 1982 Faba bean pests in Egypt. In: Faba Bean Improvement. World Crops: Production, Utilization, and Description, vol 6, eds by Hawtin G. and C. Webb, Springer, Dordrecht

Karungi J., E. Adipala, P. Nampala, M. W. Ogenga-Latigo and S. Kyamanywa 2000 Pest management in cowpea. Part 3. Quantifying the effect of cowpea field pests on grain yields in eastern Uganda. Crop Prot., 19: 343-347

Kiorboe, T. and A. G. Hirst 2008 Optimal development time in pelagic copepods. Marine Ecol. Prog. Ser., 367: 15-22

Laamari, M., L. Khelfa, and A. Coeur d'Acier 2008 Resistance source to cowpea aphid (Aphis craccivora Koch) in broad bean (Vicia faba L.): Algerian landrace collection. Afr. J. Biotechnol., 7: 2486-2490

Minkenberg, O. P. J., M. Tatar and J. A. Rosenheim 1992 Egg load as a major source of variability in insect foraging and oviposition behavior. Oikos, 65: 134-142

Morad, M. M., A. S. El-Kot, M. M. Ali and H. M. Salem 2007 Study on the mechanization of cowpea crop production under Egyptian conditions. Misr. J. Agric. Eng., 24: 450-468

Mousa K. M., I. A. Khodeir, T. N. El-Dakhakhni and A. E. Youssef 2013 Effect of garlic and eucalyptus oils in comparison to organophosphate insecticides against some piercing-sucking Faba bean insect pests and natural enemies populations. Egypt. Acad. J. Biolog. Sci., 5: 21-27

Mousa, K. M. and T. Ueno 2019 Intercropping potato with citrus trees as ecologically-based insect pest management. J. Fac. Agric., Kyushu Univ., 64: in press

Nassib A. M., S. A. Khalil and A.H.A. Hussein 1991 Faba bean production and consumption in Egypt. In: Present Status and Future Prospects of Faba Bean Production and Improvement in the Mediterranean Countries, eds by Cubero, J. I. and M. C Saxena, Zaragoza, CIHEAM, p. 127-131

Ng, J. C. K. and B. W. Falk 2006 Virus-vector interactions mediating nonpersistent and semipersistent transmission of plant viruses. Annu. Rev. Phytopathol., 44: 183-212

Ofuya, T. I. 1993 Evaluation of selected cowpea varieties for resistance to Aphis craccivora Koch (Homenoptera: Aphididae) at the seedling and podding phase. Ann. Appl. Biol., 123: 19-23

Reuveni, R. 1995 Novel Approaches to Integrated Pest Management. CRC Press. Boca Raton, FL

Rusoke, D .G. and P. R. Rubaihayo 1994 The influence of some crop protection management practices on yield stability of cowpeas. African Crop Sci. J., 2: 43-48

Singh, S. R. 1990 Insect Pests of Tropical Food Legumes, Wiley, Chichester 
Singh, S. R. and H. F. van Emden 1979 Insect pests of grain legumes. Annu. Rev. Entomol., 24: 255-278

Soffan, A. and A. S. Aldawood 2014 Biology and demographic growth parameters of cowpea aphid (Aphis craccivora) on faba bean (Vicia faba) cultivars. J. Insect Sci., 14: article 120

Stavrinides, J., J. K. McCloskey and H. Ochman 2009 Pea aphid as both host and vector for the phytopathogenic bacterium Psedomonas syringae. Appl. Environ. Microbiol., 75: 22302235

Stearns, S. C. 1989 Trade-offs in life-history evolution. Funct. Ecol., 3: 259-268

Stearns, S. C. 1992 The Evolution of Life Histories. Oxford Univ. Press, Oxford

Thomas, M. B. 1999 Ecological approaches and the development of "truly integrated" pest management. Proc. Nat. Acad. Sci. USA, 96: 5944-5951

Tran, D. H., K. P. Le, H. D. T. Tran and T. Ueno 2016 Control efficacy of pongam (Pongamia pinnata L.) leaf extract against the turnip aphid Lipaphis pseudobrassicae (Davis) (Hemiptera: Aphididae). J. Fac. Agric., Kyushu Univ., 60: $141-145$

Tran, D. H., M. Takagi and T. Ueno 2017 Efficacy of the extract from pongam leaves (Pongamia pinnata L.) against Spodoptera exigua (Hübner) and Spodoptera litura Fabricius (Lepidoptera: Noctuidae). J. Fac. Agric., Kyushu Univ., 62: 439-443
Ueno, T. 1999 Host-feeding and acceptance by a parasitic wasp (Hymenoptera: Ichneumonidae) as influenced by egg load and experience in a patch. Ecol. Ecol., 13: 33-44

Ueno, T. 2006 Current status of insect pests attacking green bunching onion in central and southern Vietnam. J. Fac. Agric., Kyushu Univ., 51: 275-283

Ueno, K. and T. Ueno 2005 Effect of wasp size, physiological state and prior host experience on host searching behavior in a parasitoid wasp (Hymenoptera: Ichneumonidae). J. Ethol., 23: 43-49

Ueno, K. and T. Ueno 2007 The effect of prior host experience and egg load on host acceptance behavior of the parasitoid Itoplectis naranyae (Hymenoptera: Ichneumonidae) on empty hosts. J. Fac. Agric., Kyushu Univ., 52: 63-67

van Emden, H. and R. Harrington 2007 Aphids as Crop Pests, Oxford Univ. Press, Oxford, UK

Vilcinskas, A. 2016 Biology and Ecology of Aphids, CRC Press, UK

Virachack, H., H. G. Trinh, T. T. G. Ho and T. Ueno 2018 Temperature effects on the development of Vietnamese cotton bollworm Helicoverpa armigera (Hübner). J. Fac. Agric., Kyushu Univ., 63: 303-309

Wang, K. and J. K. Shipp 2001 Simulation model for population dynamics of Frankliniella occidentalis on greenhouse cucumber. Environ. Entomol., 30: 1073-1081 